\title{
Meta
}

Journal des traducteurs

Translators' Journal

\section{CRONin, MiChAEL (2013): Translation in the Digital Age. New York: Routledge, 176 p.}

\section{Julie McDonough Dolmaya}

Volume 60, numéro 1, avril 2015

URI : https://id.erudit.org/iderudit/1032410ar

DOI : https://doi.org/10.7202/1032410ar

Aller au sommaire du numéro

Éditeur(s)

Les Presses de l’Université de Montréal

ISSN

0026-0452 (imprimé)

1492-1421 (numérique)

Découvrir la revue

Citer ce compte rendu

McDonough Dolmaya, J. (2015). Compte rendu de [CRONIN, MiCHAEL (2013):

Translation in the Digital Age. New York: Routledge, 176 p.] Meta, 60(1),

204-205. https://doi.org/10.7202/1032410ar

Ce document est protégé par la loi sur le droit d'auteur. L'utilisation des services d'Érudit (y compris la reproduction) est assujettie à sa politique d'utilisation que vous pouvez consulter en ligne.

https://apropos.erudit.org/fr/usagers/politique-dutilisation/
Cet article est diffusé et préservé par Érudit.

Érudit est un consortium interuniversitaire sans but lucratif composé de l'Université de Montréal, l'Université Laval et l'Université du Québec à Montréal. Il a pour mission la promotion et la valorisation de la recherche. https://www.erudit.org/fr/ 
Colón Rodríguez, Raúl Ernesto (2011): Compterendu de Francisco Lafarga et Luis Pegenaute, dir. Diccionario histórico de la traducción en España, Madrid: Gredos, 2009, 1192 p. TTR. 24(2):235-239.

De Ribera, Nicolas Joseph (1973): Descripción de la isla de Cuba: con algunas consideraciones sobre su población y comercios. La Havane: Editorial de Ciencias Sociales.

Lafarga, Francisco y Pegenaute, Luis, dir. (2009): Diccionario histórico de la traducción en España. Madrid: Gredos.

López Parada, Esperanza (2013): «Congregaciones». In: Francisco LAfarga et Luis Pegenaute, dir. Diccionario histórico de la traducción en Hispanoamérica. Madrid/ Frankfurt am Main: Iberoamericana/Veuvert, 143-145.

ORTíz, Fernando (1940/1991): Contrapunteo cubano del tabaco y el azúcar. La Havane: Editorial de Ciencias Sociales.

PAYÀs, Gertrudis (2006): Lorsque l'histoire de la traduction sert à réviser l'histoire. TTR. 19(2):15-36.

SAN Julián, Javier (2013): Translations of Historical Economic Texts into Spanish: A General Appraisal of 18th and 19th centuries. EE-T. Research paper.

Raúl ERnesto Colón Rodríguez Université d'Ottawa, Ottawa, Canada

Cronin, Michael (2013): Translation in the Digital Age. New York: Routledge, 176 p.

Translation in the Digital Age is as much about translation in the pre-digital era as it is about translation today. As Cronin argues in his introduction, "technology is not simply an accessory, an adjunct to translation, [rather] it has been central to the definition of translation activity in many different societies and in many different historical periods up to and including, of course, our own" (p. 2). For this reason, the book is replete with examples of translation and information transfer in contexts that range from translating the writings of Hermes Trismegistus into Latin in $15^{\text {th }}$-century Italy to developing automated translation devices for military use in contemporary United States. Nor does Cronin focus on a single kind of text: literary translation is discussed just as frequently as - and perhaps even more often than - digital texts like social media websites.

This wide-ranging scope is evident in the opening chapter, which contextualizes translation, technology and indeed human existence through the historical lens of "the made objects that mediate human existence" (p. 9). Turning repeatedly to historical examples that include the Rosetta
Stone, ancient Rome and medieval Italy, Cronin considers how translation, trade and technology were interconnected in early urban culture and continue to be intertwined today.

Chapter 2 focuses more particularly on the present era, exploring time, critical mass and cost as factors affecting modern translation practices. Cronin presents several interesting arguments, noting for instance that when commentators argue that translation is expensive, they often fail to compare the cost of translation with the cost of teaching everyone a lingua franca like English. He questions the notion of cost and who incurs it. Using examples as diverse as airlines requiring passengers to print boarding passes from home rather than with an agent and Google Translate allowing users to translate texts without the visible labour of a translator, Cronin argues that every transaction has a cost, but these costs can be shifted around: from producers to consumers, from people to machines. Later, he discusses the notion of power, transparency and information transfer in modern society, arguing that translation helps enable transparency, adding value to the "big data" that is accumulated when social networks like Facebook can be accessed by a greater number of users. For this reason, Cronin believes translators have an ethical responsibility to make the cost of translation more visible, since it is increasingly being shifted from content producers to the users themselves.

Historical and contemporary examples are given almost equal footing once more in Chapter 3 , which explores the idea of borders and limits in relation to translation. Cronin studies not only how Martin Luther challenged the limits of the German language with his translation of the Bible and how literary translators test limits and conventions, but also the limitations of smartphone translation apps and the limits of translation growth.

The main focus of Chapter 4 is the question of how the "culture of transparency" (p. 106) in which we now live, where our private lives are often on public display through social media, affects translation. Cronin offers several examples of how translation is informed by this culture of transparency: linguists interpreting and translating to facilitate surveillance and espionage, community interpreters making visible what would otherwise be hidden (medical symptoms, evidence at a trial, educational needs), and literary translators enabling "literary wares" (p. 107) to be showcased to others. In other cases, he offers examples more directly tied to the digital age, including Wikileaks relying on translation to make transparent "evidence of fraud, malpractice, illegal activities, or torture by private or public entitles" (p. 108).

Finally, Chapter 5 delves into Machine Translation and related issues such as post-editing and 
quality control, with a focus on details: what details are lost in machine translation, and when do these details matter? Cronin considers these questions from various angles, allowing him to weigh, for instance, the power of Internet users to understand texts against the dependency these users will develop for the MT system. He also contrasts the fact that MT provides real-time translation with the fact that it dematerializes the labour involved in translating, making the task seem effortless.

Translation in the Digital Age is an insightful take on both the past and present relationship between translators, tools and technology. The references to literary translation, to translators working centuries ago in various contexts reminds us that translating in the digital age often shares many parallels with translating in the pre-digital era.

My one small criticism relates to Cronin's comments on the ethical responsibilities of translators, which often lacked supporting examples. He argues, for instance, that translators need "make manifest the invisible, devolved translation costs of the new social media" (p. 61), and later, that they should defend "chrono-diversity" (p. 94) in the workplace, thereby preserving different rhythms and different experiences of time. In both instances, though, it would have been helpful if
Cronin had suggested specific things translators and critics could do to achieve these ethical goals. How, for instance, can we make translation costs more visible? Through promotional campaigns on the social media platforms that rely on crowdsourcing? By refusing to participate in crowdsourced projects? By participating but also using the online forums to discuss the effort involved in translation? Likewise, the intriguing idea of chrono-diversity could be further developed: while it is certainly laudable to try to respect both slow and fast work paces in an era when, as Cronin notes, the demand for quick, constant content largely means translation cannot be an artisanal practice but must instead be an industrial, semi-automated activity, it's not immediately apparent how this goal could be achieved. Some examples would have clarified the idea. But this is a minor criticism of an otherwise excellent book that successfully walks the line between examining translation and technology through either an overly optimist or an overly pessimistic eye, and instead carefully considers the relationship between translators and technology, demonstrating that translation is present in nearly all facets of the Internet era.

Julie McDonough Dolmaya York University, Toronto, Canada 